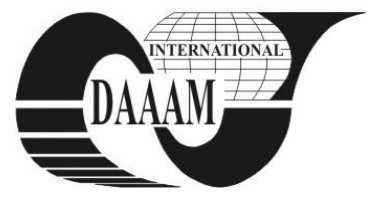

Annals of DAAAM for 2011 \& Proceedings of the 22nd International DAAAM Symposium, Volume 22, No. 1, ISSN 1726-9679 ISBN 978-3-901509-83-4, Editor B. Katalinic, Published by DAAAM International, Vienna, Austria, EU, 2011 Make Harmony between Technology and Nature, and Your Mind will Fly Free as a Bird

Annals \& Proceedings of DAAAM International 2011

\title{
RISK OF MUSCULOSKELETAL DISORDERS AND OCCUPATIONAL DISEASES
}

\author{
SEKULOVA, K[aterina] \& SIMON, M[ichal]
}

\begin{abstract}
Musculoskeletal disorders and related occupational diseasesare currently one of the most serious problems in in production and non-production areas. Therefore, it is necessary to try to avoid such problems. This article deals with current situation of occupational diseases in Czech Republic and possibilities how to prevent health problems

Key words: musculoskeletal disorders, occupational diseases, ergonomics
\end{abstract}

\section{INTRODUCTION}

Even if the production over several decades changed dramatically, manual labor is replaced by new technologies and machineries and workers do less physically demanded labor, they are still exposed to health risks, whose reasons are enforced and awkward working postures, frequent repetitive movements, effect of vibrafon on muscels and bones and many others.

Concurrently workers are also under increased mental strain, they often work under press and stress. This all contributes to origin of musculoskeletal disorders, which are frequent cause of occupational diseases. They have primarly economic and moral impact on whole society. Therefore it is important to limt and to decrease these risks and thus prevent undersirable health problems.

\section{MUSCULOSKELETAL DISORDERS}

In the course of manufacturing process, the worker has many harmful effects, which cause the workload on health.

Short-term largely resolves with rest or after work. Longterm harmful effects often lead to irreversible harm and they belong to the group of musculoskeletal disorders (Marek \& Skřehot, 2009).

Musculoskeletal disorders (MSD's) represent group of disorders, which affect muscels, joints, tendons, ligaments, nerves and bones and currently represent a very serious problem throughout Europe (Hlávková, 2007).

Most musculoskeletal disorders have a cumulative nature of damage resulting from repeated exposure to stress, high or low intensity for a long time. MSD's result in loss of productivity, financial burden and social disadvantage, not only for workers but also employers and society as a whole. MSD's affect nearly 60 million workers in 31 European countries, represent $53 \%$ of occupational diseases and they are the leading rails of causes of sick leaves (Valečková, 2010).

\section{OCCUPATIONAL DISEASES}

In the Czech Republic the occupational diseases are under $\S$ 1 paragraph 1 Government Regulation No. 290/1995 Coll., diseases emerging unfavourable influence of chemical, physical, biological or another harmful effects, if they are created under the conditions specified in the List of occupational diseases.

Diseases from this List are divided into six areas:

- Occupational diseases caused by chemical substances
- Occupational diseases caused by physical factors

- Occupational diseases of the lung, pleura and peritoneum

- Skin diseases

- Infectious and parasitic occupational diseases

- Occupational diseases caused by other factors (Fenclová et al., 2010).

Most widespread group in the Czech Republic are occupational diseases caused by physical factors. These diseases are caused already mentioned musculoskeletal disorders.

Next table presents occupational diseases in the Czech Republic, which affect musculoskeletal system.

\begin{tabular}{lll}
\hline \hline \multicolumn{2}{c}{ Occupational disease } & \multicolumn{1}{c}{ Conditions of origin } \\
\hline 1 & $\begin{array}{l}\text { Diseases of blood vessels in } \\
\text { hands while working with } \\
\text { vibrating tools and } \\
\text { machines. }\end{array}$ & $\begin{array}{l}\text { Items 1 -3: } \\
\text { Diseases developing during } \\
\text { work with hand-operated } \\
\text { pneumatic tools with such }\end{array}$ \\
$\begin{array}{l}\text { Diseases of peripheral } \\
\text { nerves of upper limbs of } \\
\text { ischemic and isthmal } \\
\text { neuropathies while working } \\
\text { with vibrating tools and } \\
\text { machines. }\end{array}$ & $\begin{array}{l}\text { values of accelerated } \\
\text { vibrations which, according } \\
\text { to current level of medical } \\
\text { knowledge, are the cause of } \\
\text { disease. }\end{array}$ \\
\end{tabular}

3 Diseases of bones and joints of hands or wrists or elbows while working with vibrating tools and machines.

4 Diseases of tendons, tendon sheaths, insertions, muscles or limb joints caused by long-term excessive onesided overtaxing.

5 Diseases of tendons, tendon sheaths, insertions, muscles or limb joints caused by long-term excessive onesided overtaxing..

6 Bursopathy caused by pressure.

Items 4-5:

Diseases develop during work when the respective muscle groups or nerves are being overtaxed to the extent that the overtaxing or pressure, tension or torsion are, according to current medical knowledge, the cause of the disease.

Disease develops during work performed in such a working position in which the afflicted area is under pressure for the majority of the working shift.

7 Meniscus damage

Disease develops during work performed in kneeling or squatting position for the majority of the working shift.

$\overline{\text { Tab. 1. Occupational diseases affecting musculoskeletal system }}$ 


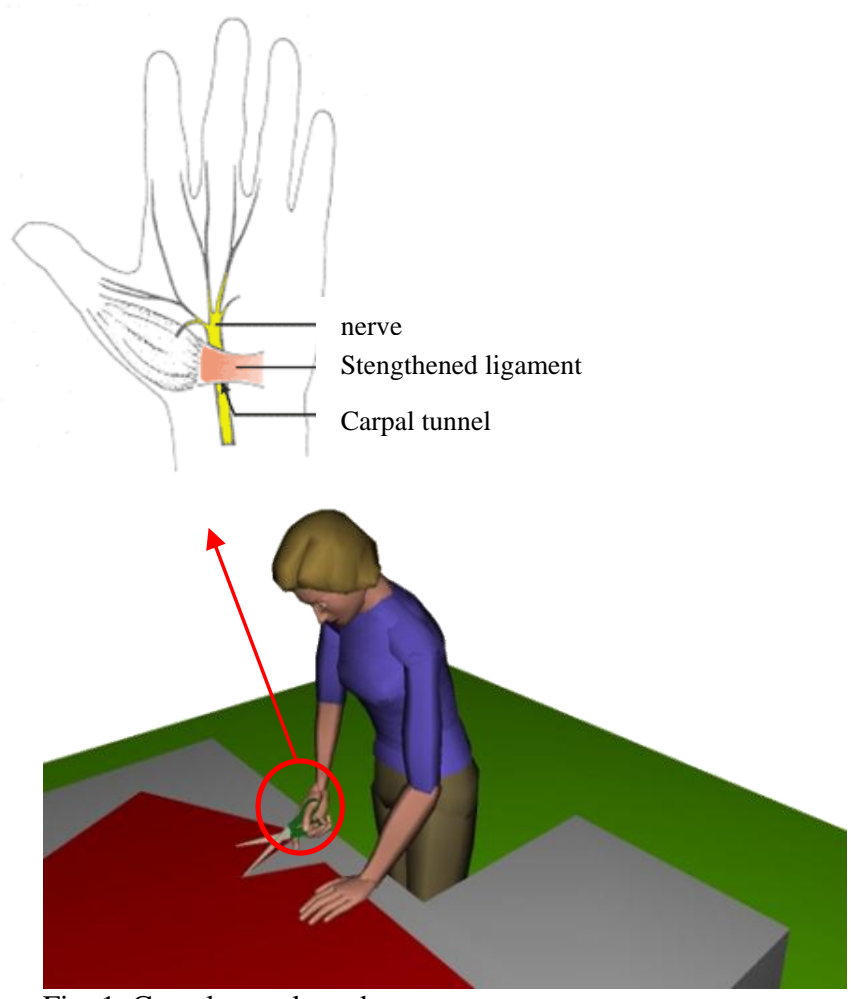

Fig. 1. Carpal tunnel syndrome

According to statistics of the National Health Institut, in 2010 occupational diseases caused by physical factors comprised $53,2 \%$ of all announced diseases and total number was 957 cases, which is the highest reported diseases from 2002 (exception 2008 with 693 cases). Long-term excessive onesided overtaxing (406 cases) and vibration (230 cases) were the main causes of these diseases.

Among most widespread diseases belongs carpal tunnel syndrome (Fig. 1). This disease is caused by long-term excessive onesided overtaxing (230 cases in 2010) and by vibrating (160 cases in 2010), carpal tunnel syndrome affects often women than men.

Most endangered working positions are from areas such as agriculture, forestry, health care, textile industry, metal industry, building industry. In 2010 there were the most diseases reported on craftsmen and qualified producers, manufacturers and repairmen, then on machines services.

\begin{tabular}{lc}
\hline \hline Diseases & number \\
\hline $\begin{array}{l}\text { Carpal tunnel syndrome caused by long-term } \\
\text { excessive onesided overtaxing }\end{array}$ & 230 \\
Carpal tunnel syndrome caused by vibrations & 160 \\
Radial humeral epicondylitis & 50 \\
$\begin{array}{l}\text { Secondary Raynaud's syndrome caused by } \\
\text { vibrations }\end{array}$ & 49 \\
Ulnar humeral epicondylitis & 28 \\
Trigger finger & 25 \\
Arthrosis of thumb & 12 \\
other synovitis and tendosynovitis & 11 \\
Ulnar nerve lesion at the elbow & 10 \\
\hline \hline Tab. 2. Most common diseases in 2010 in the Czech Republic
\end{tabular}

Tab. 2. Most common diseases in 2010 in the Czech Republic
In the previous table there are mentioned diseases, which come under group of diseases caused by physical factors. In list there are included only diseases, which affect 10 and more persons.

As I mentioned above, the most widespread disease is karpal tunnel syndrome, then follows radial humeral epicondylitis and Secondary Raynaud's syndrome caused by vibrations.

As you can see, occupational diseases still represent great risk not only for workers but also for companies, that these risks bring considerable economic losses.

In Europe just musculoskeletal disorders participate in the origin of occupational diseases and in countries EU represent losses about $3-5 \%$ gorss national product.

It is evident that we cannot ignore this area and it is necessary to pay adequate attention.

Therefore within the project Optimization of multidisciplinary design and modelling of virtual firm's production systems there was proposed model for identification of risk of occupational diseases in relation to working activity.

This model is divided into six steps, currently steps 4 and 5 are in process.

\section{CONCLUSION}

The aim is to propose a model that will be able to set the necessary criteria to determine which risks threatens worker from occupational diseases, and how likely and in what timeframe the disease may occur. On the basis of such information it will then be possible to prevent possible risks, if necessary, and seek measures to reduce their occurrence or even prevent them (Sekulová \& Šimon, 2010).

\section{ACKNOWLEDGEMENTS}

This paper was created with a subsidy from the project 402/08/H051 from the Grant Academy of the Czech Republic. The name of this project is "Optimization of multidisciplinary designing and modelling of a virtual firm's production systems".

\section{REFERENCES}

Fenclová, et al. (2010). Nemoci z povoláni v České republice. Státní zravotní ústav, ISSN 1804-5960, Praha

Hlávková, J. (2007). Nové metody ve fyziologii práce, Available from:

http://www.cmkos.cz/data/articles/down_299.ppt+onemocn $\% \mathrm{C} 4 \% 9 \mathrm{Bn} \% \mathrm{C} 3 \% \mathrm{AD}+$ pohybov\%C3\%A9ho+apar\%C3\%A $1 \mathrm{tu}+\mathrm{H} 1 \% \mathrm{C} 3 \% \mathrm{~A} 1 \mathrm{vkov} \% \mathrm{C} 3 \% \mathrm{~A} 1 \& \mathrm{~cd}=6 \& \mathrm{hl}=\mathrm{cs} \& \mathrm{ct}=\mathrm{clnk} \& \mathrm{gl}$ =cz Accessed: $2010-07-21$

Marek, J.; \& Skřehot, P.(2009). Základy aplikované ergonomie. VÚBR, ISBN 978-80-96973-6, Praha

Sekulová, K.; \& Šimon, M. (2010). The link between ergonomics and occupational diseases. Proceedings of International Conference on Industrail and Information Engineering, France. ISSN 1307-6892, Ardil, C. (Ed.), pp. 284 - 287, Paris

Valečková, A. (2010). Muskuloskeletální onemocnění, Available from:

http://www.cmkos.cz/data/articles/down_299.ppt+onemocn $\% \mathrm{C} 4 \% 9 \mathrm{Bn} \% \mathrm{C} 3 \% \mathrm{AD}+$ pohybov\%C3\%A9ho+apar\%C3\%A $1 \mathrm{tu}+\mathrm{Hl} \% \mathrm{C} 3 \% \mathrm{~A} 1 \mathrm{vkov} \% \mathrm{C} 3 \% \mathrm{~A} 1 \& \mathrm{~cd}=6 \& \mathrm{hl}=\mathrm{cs} \& \mathrm{ct}=\mathrm{clnk} \& \mathrm{gl}$ =cz Accessed: $2011-04-21$ 